\title{
ACTIVITY OF 96\% ETHANOL EXTRACT OF CHRYSOPHYLLUM CAINITO L. IN INCREASING VERTEBRAE TRABECULAR OSTEOBLAST CELL NUMBER IN MALE MICE
}

\author{
BURHAN MA'ARIF ${ }^{1 *}$, AGNIS PONDINEKARIA ADITAMA ${ }^{2}$ \\ ${ }^{1}$ Department of Pharmacy, Faculty of Medical and Health Science, Maulana Malik Ibrahim State Islamic University, Malang, East Java, Indonesia. \\ ${ }^{2}$ Depatment of Pharmacy, Pharmacy Academy of Jember, Jember, East Java, Indonesia. Email: burhan.maarif@farmasi.uin-malang.ac.id
}

Received: 08 August 2018, Revised and Accepted: 26 October 2018

\section{ABSTRACT}

Objectives: This study was conducted to analyze the anti-osteoporosis effect of $96 \%$ ethanol extract from Chrysophyllum cainito L. leaves, which suspected to contain phytoestrogens, in increasing the osteoblast cell number in trabecular vertebra bone of dexamethasone-induced male mice.

Materials and Methods: The $96 \%$ ethanol extract of $C$. cainito leaves was given to male mice with dose of 2, 4, 8, and $16 \mathrm{mg} / 20 \mathrm{~g}$ BB mice/day after being induced orally with dexamethasone dose of $0.0029 \mathrm{mg} / 20 \mathrm{~g} \mathrm{BB}$ mice/day. The positive control used was $0.026 \mathrm{ml} / 20 \mathrm{~g} \mathrm{BB}$ mice/day alendronate. After 4 weeks, the increasing of osteoblast cell number in trabecular vertebrae bone of male mice was observed using an optical microscope with $100 \times$ zoom in after histomorphometry and hematoxylin-eosin staining methods.

Results: The result showed the significant increasing of osteoblast number in trabecular vertebrae bone of male mice in all groups after being given treatment using $96 \%$ ethanol extract of $C$. cainito, with an effective dose $\left(\mathrm{ED}_{50}\right)$ value of $9.5 \mathrm{mg} / 20 \mathrm{~g}$ BB mice/day. This increase is suspected due to the phytoestrogens content, which can also act as phytotestosterone in $96 \%$ ethanol extract of $C$. cainito.

Conclusion: This study concluded that $96 \%$ ethanol extract of $C$. cainito has an activity in increasing osteoblast cell number in trabecular vertebra bone of dexamethasone-induced male mice, with an $\mathrm{ED}_{50}$ value of $9.5 \mathrm{mg} / 20 \mathrm{~g} \mathrm{BB}$ mice/day.

Keywords: Chrysophyllum cainito L., Phytoestrogens, Osteoporosis.

(c) 2019 The Authors. Published by Innovare Academic Sciences Pvt Ltd. This is an open access article under the CC BY license (http://creativecommons. org/licenses/by/4. 0/) DOI: http://dx.doi.org/10.22159/ajpcr.2019.v12i1.28994

\section{INTRODUCTION}

Osteoporosis is a condition with the degradation of bone mass along with microarchitecture damage of bone which causes the fracture risk [1,2]. Osteoporosis usually occurs in postmenopausal women, which is suffering from estrogen deficiency [3].

Giving hormone replacement therapy (HRT) is known to be a treatment that is often given to patients with estrogen deficiency. This is because HRT can replace the function of estrogen in maintaining homeostasis function of body organs including preventing osteoporosis $[3,4]$. However, in some studies, it is known that long-term administration of HRT may lead to potential side effects such as coronary events, venous thromboembolism, stroke, breast cancer, and dementia $[5,6]$

Phytoestrogens are a group of compounds derived from plants that have estrogen-like structures or can replace the function of estrogen in its bond either with estrogen receptors ([ERs]-dependent pathway) or not (ER-independent pathway) $[7,8]$. Besides being easy to obtain and having no side effects, the phytoestrogens are also reported to have activity for the treatment of estrogen deficiency [9-11], thereby providing an alternative treatment for potent osteoporosis [12].

Chrysophyllum cainito L. is a plant that is known to contain the phytoestrogens. This plant is growing a lot in East Java, Indonesia, and usually used to cure diabetes mellitus and rheumatic joints [13]. However, $C$. cainito has not been widely studied yet. In the previous studies, it was known that $C$. cainito leaves contain compounds such as alkaloid, phenol, flavonoid, triterpenoid, and sterol [14]. Either isoflavones which are included in flavonoid compounds or sterols can be estimated as phytoestrogens compounds due to their similar structure with $17 \beta$-estradiol [15].
Steroid sex hormone such as estrogen and testosterone plays an important role for growth and maintains bone density either in women or man. There is a significant relationship between bone mineral density and estrogen levels in women or testosterone in man [16]. Hence, there is a possibility that phytoestrogens in C. cainito can also act as phytotestosterone.

The aims of this study were to analyze the anti-osteoporosis effect of $96 \%$ ethanol extract from C. cainito L. leaves, in increasing the osteoblast cell number in trabecular vertebra bone of dexamethasone-induced male mice (Mus musculus), osteoblast in trabecular vertebrae bone should be counted after giving $96 \%$ ethanol extract of $C$. cainito leaves as samples. The increasing of osteoblast cell number in trabecular vertebrae bone of male mice was observed using histomorphometry and hematoxylin-eosin staining methods.

\section{MATERIALS AND METHODS}

\section{Plant material}

C. cainito leaves were taken and identified in Unit Pelaksana Teknis Materia Medica, Batu, Indonesia, on October 2017 with specimen number 1b-2b-3b-4b-6b-7b-9b-10b-11b-12b-13b-14a-15a-109b-119b-120a121b-124b-125a-126b-127a. The fresh leaves were dried and grinded to produce leaves powder.

\section{Drugs and chemicals}

The 96\% ethanol, dexamethasone, alendronate, CMC Na 0.5\%, and chloroform were obtained from Phytochemistry Laboratory in Pharmacy Department, Faculty of Medicine and Health Science, Maulana Malik Ibrahim State Islamic University, Malang. The 10\% formalin, 10\% formic acid, $70 \%$ alcohol, $3 \%$ nitrate acid, acetone, xylol, liquid paraffin, glycerin, water ammonia, and hematoxylin and eosin dye were obtained from Parasitology Laboratory, Faculty of Medicine, Brawijaya University, Malang. 


\section{Extract preparation}

The dry powder of $C$. cainito leaves was extracted with $96 \%$ ethanol using ultrasonic assisted extraction method. This process was repeated, collecting all the supernatants, which were finally evaporated in a rotary evaporator to get $96 \%$ ethanol extract. The extract prepared to produce extract suspension in water with the dose of 2, 4, 8 and $16 \mathrm{mg} / 20 \mathrm{~g} \mathrm{BB}$ mice/day.

\section{Bone specimen preparation}

Male mice were induced with dexamethasone of $0.0029 \mathrm{mg} / 20 \mathrm{~g} \mathrm{BB}$ mice/day orally. Then, each group was treated with $2,4,8,16 \mathrm{mg} / 20 \mathrm{~g} \mathrm{BB}$ mice/day samples, and $0.026 \mathrm{ml} / 20 \mathrm{~g} \mathrm{BB}$ mice/day alendronate. The treatment was given orally in 4 weeks. The next step was doing mice surgery to take the trabecular vertebrae bone. The vertebrae bone was cut in segment 2-7 and put inside the small container with $10 \%$ formalin for temporary storage. Trabecular vertebrae bone then inserted in decalcification solution (7.0 g aluminum chloride, $8.5 \mathrm{~g}$ chloride acid, and $5.0 \mathrm{ml}$ formic acid in $100 \mathrm{ml}$ water). Next step was neutralization using sodium sulfate $2 \%$ for $24 \mathrm{~h}$. Vertebrae bone then was washed using water flows for $12 \mathrm{~h}$ and rinsed with $70 \%$ alcohol. The bone then blocked using paraffin and cut using microtome. Next step was hydration using $70 \%$ alcohol and hematoxylin as the main coloring. The bone then inserted in $1 \%$ acid alcohol and water ammonia and dropped by comparator coloration $1 \%$ eosin. The bone was dehydrated using $70 \%$ alcohol. The final step was clearing using xylol and mounting by placing the bone on object glass. The observation was done using an Olympus Optical Microscope with $100 \times$ zoom in every slide.

\section{Data analysis}

The research result was analyzed using one-way ANOVA. Differences were considered significant at $\mathrm{p}<0.05$.

\section{RESULTS AND DISCUSSION}

Extraction of $30 \mathrm{~g}$ C. cainito leaves with $96 \%$ ethanol produces extracts with a yield value of $7.82 \%$. Osteoporosis condition in mice was created using dexamethasone induction with the dose of $0.0029 \mathrm{mg} / 20 \mathrm{~g} \mathrm{BB}$ mice/day. Mice with osteoporosis condition could be differentiated by looking at their bent spine (kyphotic), as shown in Fig. 1.

Dexamethasone is one glucocorticoid drug. Treating mice with glucocorticoid for 4 weeks are equal to 3-4 years of treatment for humans [16]. Glucocorticoid is an estrogen agonist which has the same steroids structure and can bind the ER and cause estrogen deficiency by the production of mRNA sulfotransferase [17]. Therefore, using
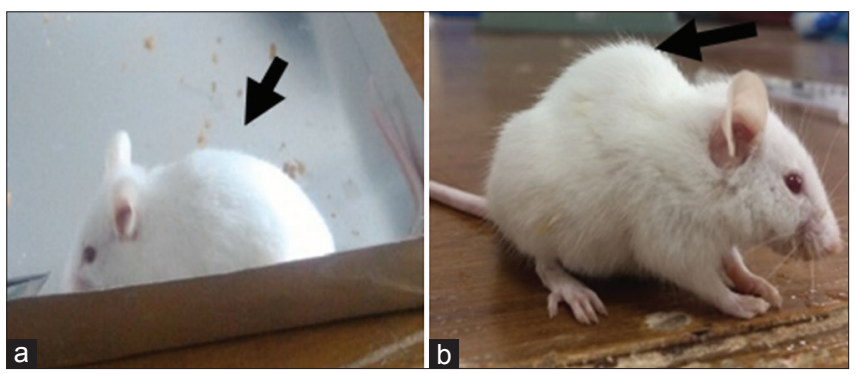

Fig. 1: (a) Normal mice and (b) mice with osteoporosis glucocorticoids for long-term therapy can cause the inhibition of bone formation process and cause osteoporosis $[17,18]$.

The retrieval of data was obtained from the osteoblast cell number calculation in trabecular vertebrae bone of male mice. All the obtained data were normally distributed and homogenous. Table 1 and Fig. 2 show the average result of total osteoblast cell number for each test group.

In one-way ANOVA statistical test, the statistical significance level was $\mathrm{p}<0.05$. It showed that there was a significant difference in the number of osteoblast cells between each group. To know the significant difference of the experimental group, post hoc test was done using LSD method. The LSD test result also showed that the significant difference between osteoblast numbers of all dosage treatment groups compares to the negative control group. It showed that $96 \%$ ethanol extract of $C$. cainito leaves in those dosages could increase osteoblast number. Besides that, LSD test result also showed the significant difference between $16 \mathrm{mg} / 20 \mathrm{~g}$ BB mice/day dose with alendronate group with value of $\mathrm{p}=0.005$. Meanwhile, for extract with the dose of 2,4 , and $8 \mathrm{mg} / 20 \mathrm{~g} \mathrm{BB}$ mice/day had $\mathrm{p}=0.559,0.895$, and 0.943 showed that $96 \%$ ethanol extract of $C$. cainito leaves on those dosages did not have significant difference compare to alendronate group.

The result showed that there is a tendency of increasing osteoblast number by giving $96 \%$ ethanol $C$. cainito leaves extract. According to LSD test result, it was found that $96 \%$ ethanol extract of $C$. cainito leaves with all dosage test has pharmacology effect. The dose of $8 \mathrm{mg} / 20 \mathrm{~g} \mathrm{BB}$ mice/day had activity level that was almost equal with alendronate, and dose of $16 \mathrm{mg}$ has better activity than alendronate in increasing the number of osteoblast cell in male mice. The histopathology of trabecular vertebrae bone of male mice can be seen in Fig. 3 .

This activity was suspected due to phytoestrogens content in $96 \%$ ethanol extract of $C$. cainito leaves that also act as phytotestosterone. It probably can happen because testosterone has the same steroid core structure as estrogen.

Long-term administration of glucocorticoids has been shown to cause hypogonadism which results in decreased testosterone levels. Whereas if the testosterone level was decreased, the bone formation will

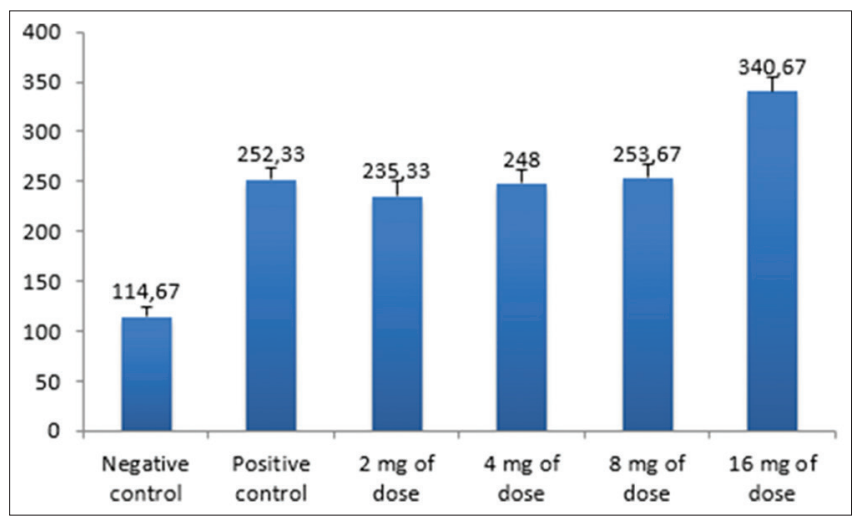

Fig. 2: Osteoblast number of each group

Table 1: Osteoblast number of each group

Groups

Positive control

Negative control

C. cainito ethanol extract dose of $2 \mathrm{mg} / 20 \mathrm{~g} \mathrm{BB}$ mice/day

C. cainito ethanol extract dose of $4 \mathrm{mg} / 20 \mathrm{~g} \mathrm{BB}$ mice/day

C. cainito ethanol extract dose of $8 \mathrm{mg} / 20 \mathrm{~g} \mathrm{BB}$ mice/day

C. cainito ethanol extract dose of $16 \mathrm{mg} / 20 \mathrm{~g} \mathrm{BB}$ mice/day

C. cainito: Chrysophyllum cainito
Average osteoblast number/five field of view \pm SD

$252.33 \pm 10.39$

$114.67 \pm 10.07$

$235.33 \pm 15.88$

$248 \pm 14.47$

$253.67 \pm 13.51$

$340.67 \pm 14.52$ 


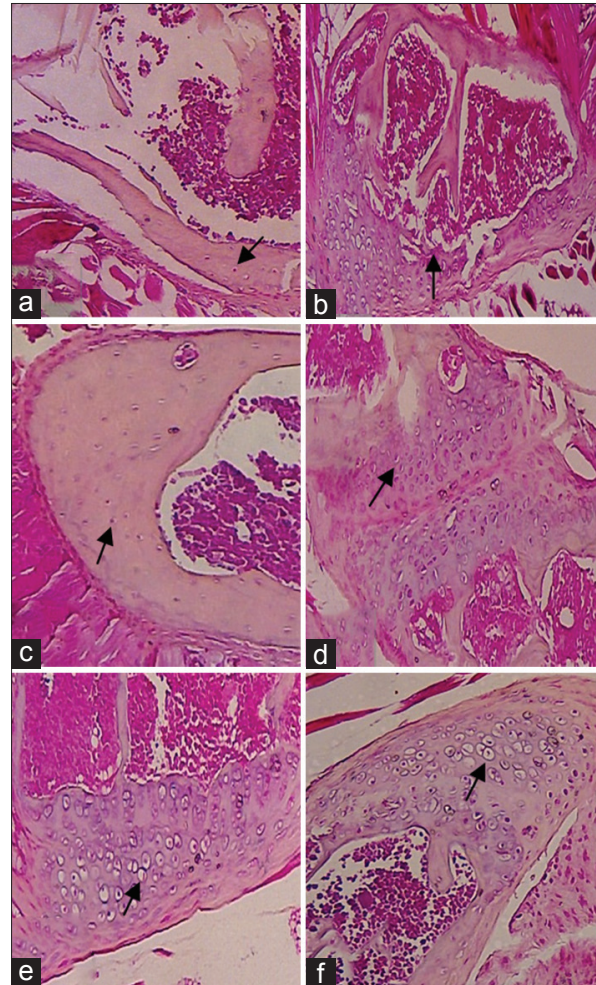

Fig. 3: Histopathology of trabecular vertebrae bone of male mice: (a) Negative control, (b) positive control, (c) dose of $2 \mathrm{mg}$, (d) dose of $4 \mathrm{mg}$, (e) dose of $8 \mathrm{mg}$, (f) dose of $16 \mathrm{mg}$

automatically be disrupted so is the case with estrogen. This is because testosterone plays a role in binding directly to androgen receptors for bone growth and maintaining bone density [19]. That is why with the administration of phytotestosterone contained in $96 \%$ ethanol extract of $C$. cainito leaves can restore bone homeostasis.

\section{CONCLUSION}

The $96 \%$ ethanol extract of $C$. cainito L. leaves had an activity to increase osteoblast cell number in trabecular vertebrae bone for male mice with $\mathrm{ED}_{50}$ is $9.5 \mathrm{mg} / 20 \mathrm{~g} \mathrm{BB}$ mice/day.

\section{AUTHORS' CONTRIBUTIONS}

The authors declare that this work was done by the author named in this article.

\section{CONFLICTS OF INTEREST}

The authors declare that they have no conflicts of interest.

\section{REFERENCES}

1. Ahmed SF, Elmantaser M. Secondary osteoporosis. Endocr Dev 2009;16:170-90

2. Agrawal V, Gupta D. Recent update on osteoporosis. Int J Med Sci Public Health 2013;2:164-8.

3. Christian B. The neuroprotective activitiesof the female sex hormone. In: Estrogens-Mystery Drug for the Brain. Wien New York: Springer; 2001.

4. Edwards BJ, Brooks ER, Langman CB. Osteoporosis screening of postmenopausal women in the primary care setting: A case-based approach. Gend Med 2004;1:70-85.

5. Taylor HS, Manson JE. Update in hormone therapy use in menopause. JClin Endocrinol Metab 2011;96:255-64.

6. Lee WL, Tsui K, Seow KM, Cheng MH, Su WH, Chen CP, et al. Hormone therapy for postmenopausal woman and unanswered issue. Gynecol Minim Invasive Ther 2013;2:13-7.

7. Cui J, Shen Y, Li R. Estrogen synthesis and signaling pathways during aging: From periphery to brain. Trends Mol Med 2013;19:197-209.

8. Sirisa-Ard P, Peerakam N, Huy NQ, On TV, Long PT, Intharuksa A. Development of anti-wrinkle cream from Pueraria candollei Var. Mirifica (airy shaw and suvat.) Niyomdham, "kwao krua kao" for menopausal women. Int J Pharm Pharm Sci 2018;10:16-21.

9. Ososki AL, Kennelly EJ. Phytoestrogens: A review of the present state of research. Phytother Res 2003;17:845-69.

10. de Villiers TJ. Bone health and osteoporosis in postmenopausal women. Best Pract Res Clin Obstet Gynaecol 2009;23:73-85.

11. Saleh DO, El-Awdan SA, Nofel SM, El-Eraky WI, El-Khatib AS, Kenawy SA. Estrogens improve the cardiovascular alterations in fructose-induced insulin resistant ovariectomized rats. Int J Pharm Pharm Sci 2015;7:241-7.

12. Yang TS, Wang SY, Yang YC, Su CH, Lee FK, Chen SC, et al. Effects of standardized phytoestrogen on Taiwanese menopausal women. Taiwan J Obstet Gynecol 2012;51:229-35.

13. Das A, Dato IR, Badaruddin BN, Amiya B. A brief review on Chrysophyllum cainito. J Pharm Herb Formul 2010;1:1-7.

14. Grippo AA, Capps K, Rougeau B, Gurley BJ. Analysis of flavonoid phytoestrogens in botanical and ephedra-containing dietary supplements. Ann Pharmacother 2007;41:1375-82.

15. N'Guessan K, Ernest AK, Marie-Solange T, Beugre K, Noeuml ZG. Effect of aqueous extract of Chrysophyllum cainito Leaves on the glycaemia of diabetic rabbits. Afr J Pharm Pharmacol 2009;3:501-6.

16. Audran M. Bone health is also for men. Medicographia 2010;32:417-21.

17. Gong H, Jarzynka MJ, Cole TJ, Lee JH, Wada T, Zhang B, et al. Glucocorticoids antagonize estrogens by glucocorticoid receptor-mediated activation of estrogen sulfotransferase. Cancer Res 2008;68:7386-93.

18. Dipiro JT, Talbert RL, Yee GC, Matzke GR, Wells BG, Possey LM. Pharmacotherapy a Pathophysiologic Approach. $9^{\text {th }}$ ed. New York: Mc Graw Hill; 2014

19. Sinnesael M, Boonen S, Claessens F, Gielen E, Vanderschueren D. Testosterone and the male skeleton: A dual mode of action. J Osteoporos 2011;2011:240328 